\title{
Inter-population thermal variability and physiological response in the intertidal fish Scartichthys viridis (Blenniidae)
}

\author{
Variabilidad térmica intrapoblacional y respuesta fisiológica en el pez intermareal \\ Scartichthys viridis (Blenniidae)
}

\author{
JOSÉ M. PULGAR ${ }^{1,2}$, FRANCISCO BOZINOVIC $^{2} \&$ F. PATRICIO OJEDA ${ }^{2 *}$ \\ ${ }^{1}$ Departamento de Ciencias Biológicas, Facultad de Ciencias de la Salud, Universidad Andrés Bello, \\ República 217, Santiago Chile \\ ${ }^{2}$ Center for Advanced Studies in Ecology and Biodiversity and Departamento de Ecología, \\ Pontificia Universidad Católica de Chile, Casilla 114-D, Santiago, 6513677, Chile \\ * e-mail for correspondence: pojeda@bio.puc.cl
}

\begin{abstract}
Determining habitat conditions that generate individual physiological variability represents key basic knowledge to understand the direction of animal's responses to habitat change. The coastal fish Scartichthys viridis inhabits low intertidal pools along the Chilean coast. Because seawater in the low intertidal is renewed during every tidal cycle, this zone is characterized by a low thermal variation and abundant food within and between localities. We evaluated whether seawater thermal conditions and food availability of low intertidal pools registered in three localities of Chilean coast are sufficient to generate physiological and energetic differences in individuals of $S$. viridis captured from three geographic separate populations spanning approximately $1,200 \mathrm{~km}$. Southern fishes acclimatized to $25^{\circ} \mathrm{C}$ showed higher metabolic rates than those from other localities and thermal treatments. On the other hand, southern fishes in natural conditions showed higher condition factor than northern fishes. This evidence is sufficient to indicate that slight latitudinal differences in tidepool seawater temperature associated to differential food availability induced an energetic constraint in this species. Moreover, southern population of $S$. viridis may suffer important effects on energetic allocation if seawater temperature increases slightly, with repercussions on its geographic distribution in southern Pacific Ocean.
\end{abstract}

Key words: intertidal fish, physiological compensation, tidepool, Scartichthys viridis.

\section{RESUMEN}

Determinar las condiciones del ambiente que generan variabilidad fisiológica, representa un conocimiento básico para comprender el sentido de la respuesta de los animales a los cambios en su hábitat. El pez costero Scartichthys viridis habita las pozas bajas del intermareal a lo largo de la costa chilena. Debido a que el agua de mar se renueva en cada ciclo de marea en las pozas bajas, esta zona está caracterizada por una baja variación térmica y abundante alimento entre localidades. Nosotros evaluamos si las condiciones térmicas y la disponibilidad de alimento descrita para pozas bajas registradas en tres localidades de la costa chilena son suficientes para generar diferencias fisiológicas y energéticas en individuos de $S$. viridis capturados desde tres poblaciones separadas geográficamente por aproximadamente $1.200 \mathrm{~km}$. Los peces del sur aclimatados a 25 ${ }^{\circ} \mathrm{C}$ mostraron una tasa metabólica mayor que los peces de las otras localidades y tratamientos. Por otra parte, en el ambiente natural, los peces del sur mostraron un factor de condición mayor que los peces del norte. Esta evidencia es suficiente para indicar que suaves diferencias latitudinales en la temperatura del agua de las pozas intermareales, asociado a una disponibilidad diferencial de alimento, promueven restricciones energéticas en esta especie. Más aun, las poblaciones del sur de $S$. viridis podrían sufrir importantes efectos en su asignación energética si la temperatura del agua incrementa suavemente, lo que repercutiría en su distribución geográfica en el océano Pacífico sur.

Palabras clave: pez intermareal, compensación fisiológica, pozas intermareales, Scartichthys viridis. 


\section{INTRODUCTION}

Studies on physiological variability between populations exposed to distinct habitats conditions are crucial for understanding how differences between populations evolve and are affected by environmental factors (Garland \& Adolph 1991). This type of study becomes a useful and effective tool for understanding the origin of variability in physiological traits (Spicer \& Gaston 1999).

Differences in physiological traits between latitudinally distant populations are, undoubtedly, a primary evidence of how selective processes mold physiological characters that allow species to compensate environmental variability, hence, persist in a given habitat (Garland \& Adolph 1991). Physiological constraints govern the relationships between abiotic variables and the limits of species' distributions (Chown \& Gaston 2000). Such physiological variability can be environmentally induced, through nongenetic mechanisms of acclimatation, or may reflect adaptations to local conditions (Stearns 1982, Spicer \& Gaston 1999).

In ectotherms environmental temperature is one of the most relevant niche axes (Tracy \& Christian 1986) since it affects numerous biological processes (i.e., assimilation, growth) and life-history traits (i.e., litter size). Therefore, since environmental temperature directly affects the energy budgets of individuals, it also has important consequences on their ecological and reproductive success (Cossins \& Bowler 1990). Moreover, in a global warming scenario there is a renewed interest in understanding how physiological mechanisms may limit environmental tolerance and determine geographic distributions of animals (Tracy \& Christian 1986, Spicer \& Gaston 1999, Carey 2005, Stevenson et al. 2005).

For many species the interaction between food and temperature has important effects on their energetic balance, because both factors finally affect their biological performance (Krause et al. 1998, Kooijman 2000, Pulgar et al. 2003).

Intertidal rock pools are characterized by their discrete nature in time and space, as well as their daily and seasonal variability in temperature, oxygen concentration and salinity (Newell 1970, Stephenson \& Stephenson 1972,
Truchot \& DuhaneJouve 1980, Metaxas \& Scheibling 1993). These physical variations, particularly temperature, depend on rock pool location along a vertical intertidal gradient, which determines the length of time that a rock pool remains isolated from the subtidal system during ebb time. For mobile predators such as fishes, the abundance and food quality of rockpools are also affected by the distance from the shore, being higher in low than in high tidepools (Gibson 1972, 1982, Raffaelli \& Hawkins 1986, Horn \& Gibson 1988, Horn et al. 1999, Metaxas \& Sheibling 1993, Pulgar et al. 1993). Along the Chilean coast the abundance and diversity of macroalgae sharply increase southward (Santelices \& Marquet 1998, Vásquez et al. 1998, Aldana et al. 2002).

Intertidal fish assemblages are composed of resident and transitory species (Horn et al. 1999). Recent studies indicated that resident species are mainly found in low intertidal pools (Thompson \& Lehner 1976, Pulgar et al. 2005). Scartichthys viridis (Blenniidae, Valenciennes, 1836) is the most abundant resident herbivorous fish species inhabiting low intertidal pools from 18 to $40^{\circ} \mathrm{S}$ along the Chilean coast (Stepien 1990, Varas \& Ojeda 1990, Ojeda et al. 2000). Given the wide geographic distribution of this species and based on previous studies that have shown - along the Chilean coast - a sharp increase in abundance and diversity of macroalgae southward, we evaluated whether physical variations in seawater temperature of low intertidal rock pools are able to generate energetic differences in Scartichthys viridis from geographic separate populations spanning approximately $1,200 \mathrm{~km}$. To this, we evaluated the condition factor $(\mathrm{K})$ as an indicator of degree of robustness (muscular tissue) of fish (Moyle \& Cech 1982) and metabolic rate as indicator of energetic cost of life associated to particular habitat condition (Schmidt-Nielsen 1997).

\section{MATERIAL AND METHODS}

At each geographic locality, we characterized low tide pool seawater thermal variations using temperature data loggers (Unisource, Table 1, see Pulgar et al. 2005). We considered low tide pools as those located nearest $(1-2 \mathrm{~m})$ to low tide mark (MLWL). Preliminary observations indicated that seawater of these tide pool was 
renewed in every tidal cycle. Specimens were captured from tide pools in winter 2001 and summer 2002 from three localities along the Chilean coast, Antofagasta $\left(23^{\circ} 20^{\prime} \mathrm{S}, 70^{\circ} 38^{\prime} \mathrm{W}\right)$, Carrizal Bajo $\left(28^{\circ} 04^{\prime} \mathrm{S}, 71^{\circ} 08^{\prime} \mathrm{W}\right)$ and Las Cruces $\left(33^{\circ} 26^{\prime} \mathrm{S}, 71^{\circ} 41^{\prime} \mathrm{W}\right)$. Specimens were transported to Las Cruces Coastal Marine Research Station (ECIM) where they were maintained under laboratory conditions.

\section{Condition factor $(\mathrm{K})$}

Standard length $\left(\mathrm{L}_{\mathrm{T}}\right)$ and body mass $(\mathrm{Mb})$ of each fish was registered using a caliper $( \pm 0.1$ $\mathrm{cm})$ and electronic balance $( \pm 0.1 \mathrm{~g})$, respectively. The condition factor $(\mathrm{K})$ was calculated through the equation $\mathrm{K}=\mathrm{Mb} / \mathrm{L}_{\mathrm{T}}{ }^{3}$ (Wootton 1991). To avoid differences in body mass and sex of animals sampled among different localities and seasons (winter and summer), $\mathrm{K}$ was only evaluated in prereproductive fishes, i.e., $\mathrm{L}_{T}<13 \mathrm{~cm}$ (Stepien 1990).

\section{Metabolic rate}

Fishes were maintained in two thermal separated groups of 15 and $25{ }^{\circ} \mathrm{C}$ for 45 days with ventilated circulating seawater, ad-libitum food (the green macroalgae Ulva spp.), and LD = 12: 12 photoperiod. This acclimated period was selected to delete the effect of local habitat conditions on metabolic response of fishes. Moreover, these temperatures correspond to the nearest extreme thermal condition observed along the geographic studied range (Table 1).
In order to avoid digestion costs, all fish were maintained in starvation during 48 hours previous to measurements of oxygen consumption $\left(\mathrm{VO}_{2}\right)$. To avoid endogenous cycles of intertidal individuals (Horn et al. 1999), all measurements were conducted between 12:00 to 16:00 $\mathrm{h}$ in animals captured in summer and winter. A total of 10, 13, and 10 fishes collected in Antofagasta, Carrizal Bajo and Las Cruces, respectively, were acclimated to $15^{\circ} \mathrm{C}$; while 11,13 and 12 fishes collected at the same localities were acclimated to $25{ }^{\circ} \mathrm{C}$. Each fish was deposited in dark metabolic chambers for two hours previous to $\mathrm{VO}_{2}$ measurement. During this time seawater was maintained saturated with $\mathrm{O}_{2}$ at constant temperature of 15 ${ }^{\circ} \mathrm{C}\left(8.30 \mathrm{mg} \mathrm{O}_{2} \mathrm{~L}^{-1}\right)$ or $25{ }^{\circ} \mathrm{C}\left(6.71 \mathrm{mg} \mathrm{O}_{2} \mathrm{~L}^{-1}\right)$ (Green \& Carrit 1967). Later, the metabolic chamber was sealed and an $\mathrm{O}_{2}$ electrode (Strathkelvin model 1302) was connected to Strathkelvin model 781 oxygenmeter. This instrument recorded the decrease in seawater percentage of $\mathrm{O}_{2}$ inside the closed metabolic chamber. Metabolic rate was expressed as $\mathrm{mg} \mathrm{O}_{2}$ $\mathrm{g}^{-1} \mathrm{~h}^{-1}$. For all fishes, $\mathrm{VO}_{2}$ mesurements were stopped when $\mathrm{O}_{2}$ percentage reached $70 \%$ within the metabolic chamber.

\section{Statistical analysis}

Differences in $\mathrm{K}$ - values and body size of fishes among localities and season were tested by a two-way ANOVA. We used a-posteriori Tukey test in orden to evaluate specific groups (Zar 1996). To determine effect of body size, locality and thermal treatments on metabolic rate of

TABLE 1

Mean minimal and maximal seawater temperature $\left({ }^{\circ} \mathrm{C}\right)$ registered in low intertidal pools from three localities during winter and summer along the Chilean coast.

Temperatura mínima y máxima promedio $\left({ }^{\circ} \mathrm{C}\right)$ registrada en las pozas del intermareal bajo de tres localidades durante verano e invierno en la costa chilena

\begin{tabular}{lccc}
\hline Season & Locality & Minimal temperature $( \pm 1$ SE) & Maximal temperature $( \pm 1$ SE) \\
\hline Winter & Antofagasta & $14.66 \pm 0.20$ & $18.77 \pm 0.20$ \\
Summer & Antofagasta & $15.66 \pm 0.14$ & $25.31 \pm 0.25$ \\
Winter & Carrizal Bajo & $12.82 \pm 0.15$ & $15.53 \pm 0.29$ \\
Summer & Carrizal Bajo & $15.86 \pm 0.13$ & $20.33 \pm 0.24$ \\
Winter & Las Cruces & $12.75 \pm 0.14$ & $13.67 \pm 0.26$ \\
Summer & Las Cruces & $15.13 \pm 0.15$ & $18.03 \pm 0.31$
\end{tabular}


fishes we used a Components of Variance test followed by a two-way ANOVA (Zar 1996). Locality, season and thermal treatments were considered fixed factors, because they represent endpoints of thermal variability along the geographic range studied. A significance level of $\mathrm{P}<0.05$ was assumed throughout the study.

\section{RESULTS}

\section{Condition factor}

Condition factor of $S$. viridis was determined only for geographic locality from which fish were captured (Table 2, Fig. 1). Las Cruces fishes were more robust than any other individuals sampled in others localities (aposteriori Tukey test $\mathrm{P}<0.05)$.

\section{Metabolic rate}

Body size of fishes in which metabolic rates was measured was not different among localities or thermal acclimation treatments (Two way Anova $F_{(2,63)}=0.37, P=0.60$, Fig. 2).
Component of variance test indicated that locality and thermal treatment significantly affect metabolic rate in this fish species (Table 3 ). The results of the two way Anova indicated that fishes from Las Cruces acclimated to $25{ }^{\circ} \mathrm{C}$ showed higher metabolic rates than those from other acclimated conditions and localities (Table 4, a- posteriori Tukey test $\mathrm{P}<0.05$ ). On the other hand, fishes from Antofagasta and Carrizal Bajo acclimated to $15{ }^{\circ} \mathrm{C}$ showed higher metabolic rates than those from Las Cruces fishes also aclimated to $15{ }^{\circ} \mathrm{C}$ (aposteriori Tukey test, Fig. 3).

\section{DICUSSION}

Considering possible effects of climatic change, many physiological ecologists are taking a renewed interest in understanding the role of temperature in determining performance capabilities of animals and their geographic distribution patterns (Huey \& Kingsolver 1993, Helmuth et al. 2002, Carey 2005). Along this line, several studies have shown correlations between animals' energetic performance and

TABLE 2

Two-way Anova to evaluate the effects of seasons and locality on condition factor of S. viridis

Evaluación mediante Anova de dos vías del efecto de la estación del año y localidad sobre el factor de condición de S. viridis

\begin{tabular}{lcccc}
\hline Effect & Degrees of freedom & Mean square & F-value & P-value \\
\hline Locality & 2 & 0.0002 & 6.19 & 0.002 \\
Season & 1 & 0.0001 & 1.08 & 0.29 \\
Locality *season & 2 & 0.00001 & 0.21 & 0.80 \\
Error & 259 & & & \\
\hline
\end{tabular}

TABLA 3

Variance component analysis evaluating the effect of body size, locality, and thermal treatment on metabolic rate of $S$. viridis

Resultados del análisis de componente de varianza para evaluar el efecto del tamaño corporal y tratamiento térmico sobre la tasa metabólica de $S$. viridis

\begin{tabular}{|c|c|c|c|c|}
\hline Effect & Degrees of freedom & Mean square & F-value & P-value \\
\hline Body size & 1 & 0.11 & 3.03 & 0.08 \\
\hline Locality & 2 & 0.17 & 4.79 & 0.011 \\
\hline Thermal treatement & 1 & 0.47 & 12.98 & 0.0001 \\
\hline Locality*thermal treatment & 2 & 0.93 & 25.56 & 0.0001 \\
\hline Error & 62 & & & \\
\hline
\end{tabular}




\section{TABLE 4}

Two-way anova to evaluate the effect of thermal treatment and geographic locality on metabolic rate in S. viridis

Resultado del análisis de varianza de dos vías para evaluar el efecto del tratamiento térmico y de la localidad geográfica sobre la tasa metabólica de $S$. viridis

\begin{tabular}{lcccc}
\hline Effect & Degrees of freedom & Mean square & F-value & P-value \\
\hline Locality & 2 & 0.12 & 3.86 & 0.026 \\
Thermal treatment & 1 & 0.61 & 16.91 & 0.0001 \\
Locality*thermal treatment & 2 & 0.95 & 26.04 & 0.0001 \\
Error & 63 & & & \\
\hline
\end{tabular}

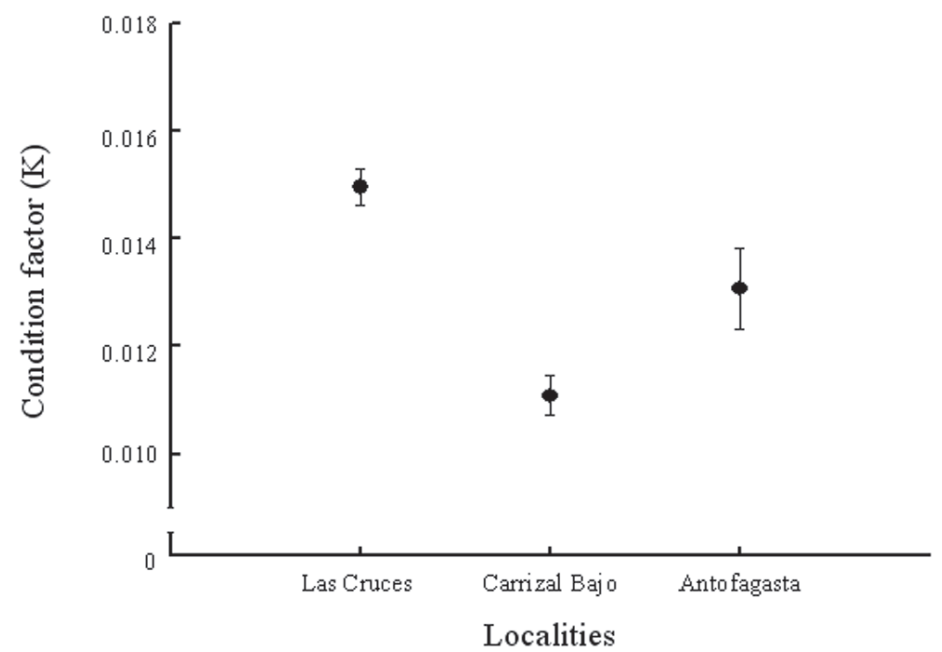

Fig. 1: Condition factor of S.viridis captured from three study localities along the Chilean coast. Error bars indicate \pm 1 standard error.

Factor de condición de S. viridis capturados en tres localidades a lo largo de la costa de Chile. Barras de error indican \pm 1 error estándar.

environmental temperature along latitudinal or altitudinal distribution ranges (see Bozinovic \& Rosenmann 1988, Root 1988, Rezende et al. 2004). As pointed out by Carey (2005) a frequent biota response to climate change is usually associated to alteration in their range of geographical distribution. This is important because movement into new habitats is likely to expose organisms not only to new climatic conditions but also to new ecological scenarios in terms of species interactions (Hughes 2000).

Prior to test our ability in predicting the effects of global change or large-scale oceanographic conditions (i.e., El Niño) on physiological variation patterns and geographical distribution (Barry et al. 1995, Spicer \& Gaston 1999), we need a basic knowledge of the environmental conditions that modify energy budgets of individuals.

In our study, lowest temperatures were recorded in Las Cruces during winter, and highest in Antofagasta during summer. On the other hand, a north-south geographic increment in food availability (macroalgae) has been described for the Chilean coast (Santelices \& Marquet 1998, Vásquez et al. 1998, Aldana et al. 2002). These facts suggest that southern fishes are exposed to less extreme thermal conditions in more productive habitats than northern fishes.

Our evidence indicates that pre-reproductive fishes from the southern population (Las Cruces) had more muscle tissue than individuals captured in northern localities 


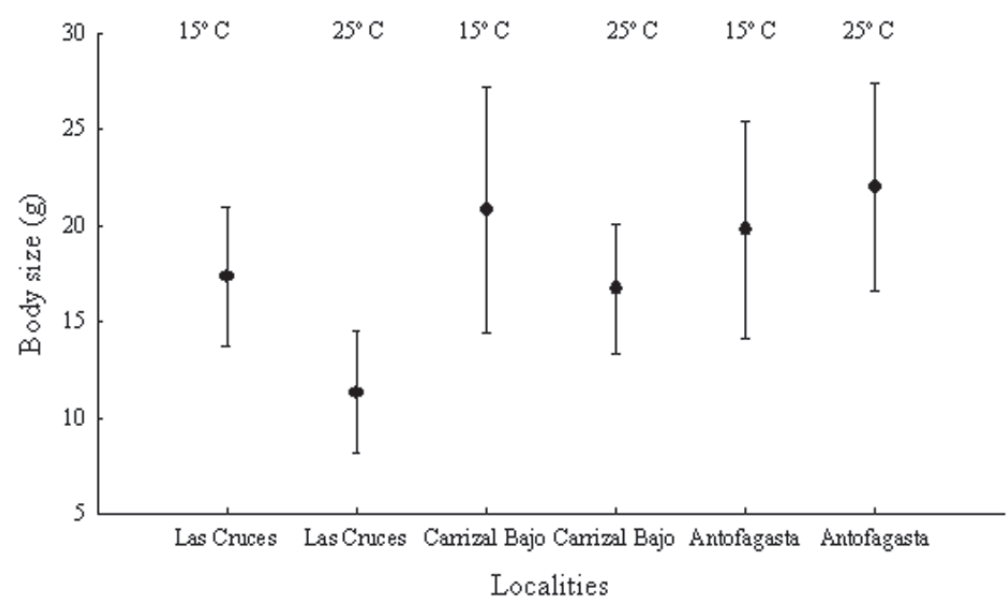

Fig. 2. Body size of S.viridis captured from three study localities along the Chilean coast in which metabolic rate was measured. Error bars indicate \pm 1 standard error.

Tamaño corporal de peces capturados desde tres localidades en la costa de Chile en los que se midió la tasa metabólica. Las barras de error indican \pm 1 error estándar.

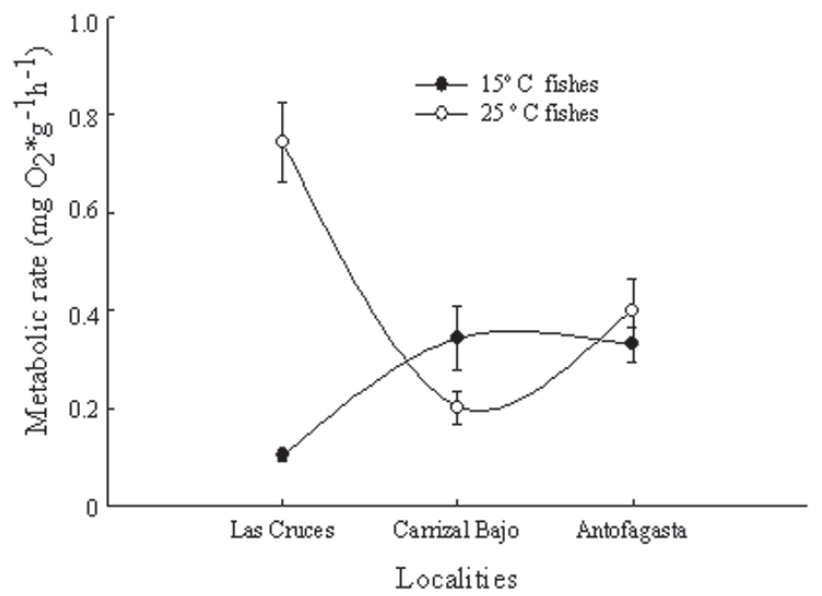

Fig. 3. Metabolic rate of $S$. viridis captured from three study localities along the Chilean coast acclimated to 15 and $25^{\circ} \mathrm{C}$. Error bars indicate \pm 1 standard error.

Tasa metabólica de $S$. viridis capturados en tres localidades a lo largo de la costa chilena aclimatados a 15 y $25{ }^{\circ} \mathrm{C}$. Las barras de error indican \pm 1 error estándar.

(Carrizal Bajo and Antofagasta) (Fig. 1, Table 1). Lowest seawater temperatures observed in Las Cruces, and food availability variation reported along the Chilean coast can modify $S$. viridis physiological responses, and may well explain the highest $\mathrm{K}$-values showed for this species at this location.

Experimental studies that evaluated temperature-fish relationships indicated that fishes could detect variations in water temperature as low as $0.1{ }^{\circ} \mathrm{C}$ (Norris 1963), showing clear selective thermoregulatory behaviour and compensation mechanism to tolerate thermal environmental variability (Pulgar et al. 1999, 2003, Spicer \& Gaston 1999). Our thermal acclimation treatements were nearest to extreme (minimun and maximun) temperatures registered in natural conditions in Chilean coast (Table 1). In this sense our results showed that fish acclimated to $25{ }^{\circ} \mathrm{C}$ from Las Cruces showed highest metabolic rates (Fig. 3) while nothern fishes accclimated to $15{ }^{\circ} \mathrm{C}$ (Carriza Bajo and Antofagasta) showed highest metabolic rate 
compared with the former (Fig. 3). These results may well be explained by thermal pool conditions where this species occurs. The $25^{\circ} \mathrm{C}$ treatement used in our study represent an unusual thermal condition for the southern $S$. viridis population (Table 1, Fig. 3), and may be nearest to their lethal temperature.

On the other hand northern fishes showed similar metabolic rate between individuals maintained at 15 and $25{ }^{\circ} \mathrm{C}$ (Fig. 3). This evidence indicates high compensation capability of these populations because they are usually exposed to both thermal conditions at those latitudes (Spicer \& Gaston 1999, Table 1 and Fig 3).

Our results indicate inter-population physiological thermal differences in S. viridis along the Chilean coast. These differences reflect environmental variability to which individuals of each population are exposed to natural conditions (Table 1). High habitat variability induced modifications of energetic budget, which associated to low food availability as in the case of northern fishes, result in a low condition factor (Fig. 1,3). On the other hand, habitat thermal stability associated to high food availability as in the case of southern fishes, result in a high condition factor (Fig. 1, 3).

Due to their ectothermic nature, changes in two important niche axes - habitat temperature and food availability - may induce an energetic constraint in this species. Southern population of $S$. viridis may suffer important effects on energy allocation if seawater temperature increases, probably affecting its geographic distribution in the southern Pacific Ocean, as it has been observed in some marine invertebrates (Barry et al. 1995). This point could be relevant when fish are confronted to the occurrence of oceanographic phenomena such as El Niño, because during these events seawater temperature may reach their lethal limits at some latitudes (Hill\& Magnuson 1990). Thermal consequences of global change in animals, particularly in fishes, will depend at least on the capacity of animals to acclimatize to new habitat conditions (Carey 2005). Thus, we can predict that animals that inhabit more stable habitat will show a more limited capacity to acclimatize and may be restricted in their ability to survive and reproduce under scenarios of climate changes.

\section{ACKNOWLEDGEMENT}

This study was funded by FONDECYT 2010128, UNAB D.I. 08-04 and AR 01-06 grants to J. Pulgar. FB and FPO acknowledge a FONDAP 1501-0001 (programs 1 and 5, respectively). We thank Álvaro Palma and Randy Finke for comments and suggestions that greatly improved the manuscript.

\section{LITERATURE CITED}

ALDANA M, J PULGAR, F OGALDE \& FP OJEDA (2002) Morphometric and parasitological evidence for ontogenetic and geographic dietary shifts in fish. Bulletin of Marine Science 71: 55-74.

BARRY JP, CH BAXTER, RD SAGARIN \& E GILMAN (1995) Climatic-related, long-term faunal changes in a California rocky intertidal community. Science 267: 672-675.

BOZINOVIC F \& M ROSENMANN (1989) Maximum metabolic rate of rodents: physiological and ecological consequences on distributional limits. Functional Ecology 3: 173-181.

CAREY C (2005) How physiological methods and concepts can be useful in conservation Biology. Integrative Comparitive Biology 45: 4-11.

COSSINS AR \& K BOWLER (1987) Temperature Biology of Animals. Chapman and Hall, New York and London. 339pp.

CHOWN SL \& KL GASTON (2000) Areas, cradles and museums: the latitudinal gradient in species richness. Trends in Ecology and Evolution 8: 310325.

GARLAND TJr \& SC ADOLPH (1991) Physiological differentiation of vertebrate Populations. Annual Review of Ecology and Systematic 22: 193-228.

GIBSON RN (1972) The vertical distribution and feeding relationship of intertidal fish on the Atlantic coast of France. Journal of Animal Ecology 41: 189-207.

GIBSON RN (1982) Recent studies on the biology of intertidal fish. Oceanographic Marine Biology Annual Review 20: 263-414.

GREEN EJ \& DE CARRIT (1967) New Tables for Oxygen Saturation. Journal of Marine Research 25: 140147

HELMUTH BD, G HARLEY, PM HALPIN, M O'DONELL, GE HOFMANN \& CA BLANCHETTE (2002) Climate change and latitudinal patterns of intertidal thermal stress. Science 298: 1015-1017.

HILL DK \& JJ MAGNUSON (1990) Potential effects of global climate warming on the growth and prey consumption of Great lake Fish. Transactions of the American Fisheries Society 119: 265-275.

HUEY RB \& JG KINGSOLVER (1993) Evolution of resistance to high temperature in ectotherms. American Naturalist 142: S21-S46.

HUGHES L (2000) Biological consequences of global warming: is the signal already. Tree 15: 56-61.

HORN MH \& RN GIBSON (1988) Intertidal fish. Scientific American 258: 54-60.

HORN MH, KL MARTIN \& MA CHOKOWSKI (1999) Intertidal fishes: life in two worlds. Academic Press, San Diego, California, USA. 399pp. 
KRAUSE J, G STAAKS \& T MEHNER (1998) Habitat choice in schoals of roach as a function of water temperature and feeding rate. Journal of Fish Biology 53: 377-386.

KOOIJMAN SALM (2000) Dynamic Energy and Mass Budget in Biological Systems. Cambridge University Press, Cambridge, UK. 448pp.

METAXAS A \& RE SCHEIBLING (1993) Community structure and organization of tidepools. Marine Ecology Progress Series 98: 187-198.

MOYLE PB \& JJ CECH (1982) Fish: an introduction to Ichthyology. Prentice Hall, Englewood Cliffs, New Jersey, USA. 593pp.

NEWELL RC (1970) Biology of intertidal animals. Marine Ecological Survey, UK. 781pp.

NORRIS KS (1963) The functions of temperature in the ecology of the percoid fish Girella nigricans (Aires). Ecological Monograph 33: 23-62.

OJEDA FP, FA LABRA \& AA MUÑOZ (2000) Biogeographic patterns of Chilean littoral fish. Revista Chilena de Historia Natural 73: 625-641.

PULGAR J, F BOZINOVIC \& FP OJEDA (1999) Behavioral thermoregulation in the intertidal fish Girella laevifrons (Kyphosidae): the effect of starvation. Marine and Freshwater Behavior and Physiology 32: 27-38.

PULGAR J, M ALDANA, F BOZINOVIC \& FP OJEDA (2003) Does food quality influence thermoregulatory behavior in the intertidal fish Girella laevifrons? Journal Thermal Biology 28: 539-544.

PULGAR J, F BOZINOVIC \& FP OJEDA (2005) Local distribution and thermal ecology of two intertidal fishes. Oecologia 142: 511-520.

REZENDE EL, F BOZINOVIC \& TJr GARLAND (2004) Climatic adaptation and the evolution of maximum and basal rates of metabolism in rodents. Evolution 58: 1361-1374.

RAFFAELLI D \& S HAWKINS (1996) Intertidal Ecology. Chapman and Hall, London. UK. 356 pp.

ROOT T (1988) Energy constraints on avian distributions and abundances. Ecology 69: 330-339.

SANTELICES B \& P MARQUET (1998) Seaweeds, latitudinal diversity patterns, and Rapoport's Rule. Diversity and Distribution 4: 71-75.

SCHMIDT-NIELSEN K (1997) Animal Physiology. Cambridge: Cambridge University Press, 242 pp.
SCHENEIDER SH \& TL ROOT (1996) Ecological implications of climatic change will include surprises. Biodiversity and Conservation 5: 1109 1119 .

SPICER JL \& KJ GASTON (1999) Physiological diversity and its ecological implications. Blackwell Science, Oxford. $241 \mathrm{pp}$

STEPIEN CA (1990) Population structure, diets and biogeographic relationships of a rocky intertidal fish assemblage in central Chile: High levels of herbivory in a temperate system. Bulletin of Marine Science 47: 598-612.

STEPHENSON TA \& A STEPHENSON (1972) Life between tidemarks on rocky shore. Freeman, San Francisco, California. 425 pp.

STEARNS SC (1982) The evolutionary significance of phenotypic plasticity. Bioscience 7: 436-445.

STEVENSON RD, SR TUBERTY, PL DE FUR \& JC WINGFIELD (2005) Ecophysiology and conservation: the contribution of endocrinology and immunology - Introduction to the symposium. Integrative Comparisons Biology 45: 1-3.

TRACY CR \& KA CHRISTIAN (1986) Ecological relations among space, time, and thermal niche axes. Ecology 67: 609-615.

TRUCHOT JP \& A DUHANEL-JOUVE (1980) Oxygen and carbon dioxide in the marine intertidal environments: diurnal and tide changes in rockpools. Respiratory Physiology 39: 241-254.

THOMPSON DA \& CE LEHNER (1976) Resilience of a rocky intertidal fish community in a physical unstable environment. Journal Experimental Marine Biology and Ecology 22: 1-29.

VARAS E \& FP OJEDA (1990) Intertidal fish assemblages of the central Chilean coast: diversity, abundance and trophic patterns. Revista de Biología Marina, Montemar 25: 59-70.

VÁSQUEZ JA, PA CAMUS \& FP OJEDA (1998) Diversidad, estructura y funcionamiento de ecosistemas costeros rocosos del norte de Chile. Revista Chilena de Historia Natural 71: 479-499.

WOOTTON RJ (1991) Ecology of teleost fishes. Chapman and Hall, London, UK. 404 pp.

ZAR J (1996) Biostatistical analysis. Princete Hall, Englenwood Cliffs, New York, USA. 